\title{
Influence of Celebrity Endorser, Attractiveness and Packaging Impressions on Interest in Watching Pesbukers ANTV
}

\author{
Kharisma Aprilian and Adil Fadillah \\ Wako University \\ adil_f@stiekesatuan.ac.id
}

\begin{abstract}
RESEARCH OBJECTIVES is to determine the effect of Celebrity Endorser, Impressions Attractiveness, Impression packaging and Interest in Watching of Pesbukers ANTV Television program(1) to know the effect of Celebrity Endorser to Interest in Watch (2) to know the effect of Impressions Attractiveness to Interest in Watch (3) to determine the effect of Impressions Packaging to Interest in Watch (4). The number of respondents in this study amounted to 100 respondents taken from students / I Sekolah Tinggi Ilmu Ekonomi Kesatuan Bogor. This research data in though by using SPSS. RESEARCH METHODS used is to use quantitative research that places the celebrity endorser, Attractiveness Impressions, and packaging Impression as independent variable and interest in watching as a dependent variable. With primary data used is questionnaires distributed to selected respondents and processed the results with statistical calculations. RESULTS Y $=-0,820+++0,353 \mathrm{X} 3+$ Which in this case means if the celebrity endorser is 1 (one) then the interest in watching value will be 0,207 . If the attractiveness imprression is 1 (one) then the interest in watching will be 0,568 . If the packaging impression is 1 (one) then the interest in watching will be 0,353 .
\end{abstract}

Keywords: Celebrity Endorser, Attractiveness Impressions, packaging Impression, Interest in Watching 